\title{
ANAEROBIC CO-DIGESTION OF CRUDE GLYCERIN AND STARCH INDUSTRY EFFLUENT
}

\author{
ANDREA C. LARSEN ${ }^{1}$, BENEDITO M. GOMES ${ }^{2}$, SIMONE D. GOMES ${ }^{3}$, \\ DILCEMARA C. ZENATTI ${ }^{4}$, DOUGLAS G. B. TORRES ${ }^{5}$
}

\begin{abstract}
The Brazil's Biodiesel Production and Use Program introduces biodiesel in the Brazilian energy matrix, bringing along the perspective of a growth of the glycerin offer, co-product generated in the proportion of $10 \mathrm{~kg}$ for each $100 \mathrm{~L}$ of biodiesel. The aim of this study was to evaluate the addition of crude glycerin in the anaerobic digestion of cassava starch industry effluent (cassava wastewater), in a horizontal semi-continuous flow reactor of one phase in laboratory scale. It was used a reactor with a $8.77 \mathrm{~L}$ of useful volume, a medium support for corrugated conduit of polyvinyl chloride (PVC), temperature of $26 \pm 1^{\circ} \mathrm{C}$, fed with cassava wastewater and glycerin, with hydraulic detention times of 4 and 5 days and increasing volumetric organic load of 3.05; 9.32; 14.83 and $13.59 \mathrm{~g} \mathrm{COD} \mathrm{L}^{-1} \mathrm{~d}^{-1}$, obtained with the addition of glycerin at $0 ; 2 ; 3$ and $2 \%(\mathrm{v} / \mathrm{v})$, respectively. The average removal efficiencies of TS and TVS were decreasing from the addition of glycerin to the cassava wastewater, averaging 81.19 to $55.58 \%$ for TS and 90.21 to $61.45 \%$ for TVS. The addition of glycerin at $2 \%$ increased the biogas production compared to the control treatment, reaching $1.979 \mathrm{~L} \mathrm{~L}^{-1} \mathrm{~d}^{-1}$. The biogas production as a function of the consumed COD was higher for the control treatment than for the treatments with addition of glycerin, which indicates lower conversion of organic matter into biogas.
\end{abstract}

KEYWORDS: cassava wastewater, biodiesel, biogas, glycerol.

\section{CODIGESTÃO ANAERÓBIA DE GLICERINA BRUTA E EFLUENTE DE FECULARIA}

RESUMO: O Programa Nacional de Produção e Uso do Biodiesel introduziu o biodiesel na matriz energética brasileira, trazendo a perspectiva de aumento da oferta de glicerina, coproduto gerado na proporção de $10 \mathrm{~kg}$ para cada $100 \mathrm{~L}$ de biodiesel. O objetivo principal deste trabalho foi avaliar a adição de glicerina bruta na digestão anaeróbia de efluente de indústria de fécula de mandioca (manipueira), em reator de fluxo semicontínuo horizontal de uma fase, em escala de laboratório. Foi utilizado um reator com volume útil de $8,77 \mathrm{~L}$, meio suporte em eletroduto corrugado de policloreto de vinila (PVC), temperatura de $26 \pm 1^{\circ} \mathrm{C}$, alimentado com manipueira e glicerina, aplicando-se tempos de detenção hidráulica de 4 e 5 , dias e cargas orgânicas volumétricas crescentes de 3,05; 9,32; 14,83 e 13,59 g COD L L $^{-1}$, obtidas com a adição de glicerina aos níveis de 0; 2; 3 e 2\% (v/v), respectivamente. As eficiências de remoção média de ST e STV foram decrescendo a partir da adição de glicerina à manipueira, com médias de 81,19 a 55,58 \% para ST e 90,21 a 61,45\% para STV. A adição de glicerina em $2 \%$ aumentou a produção de biogás em relação ao tratamentocontrole, chegando a $1,979 \mathrm{~L} \mathrm{~L}^{-1} \mathrm{~d}^{-1}$. A produção de biogás em função da DQO consumida foi maior para o tratamento-controle que, para os tratamentos com adição de glicerina, indica menor conversão da matéria orgânica em biogás.

PALAVRAS-CHAVE: manipueira, biodiesel, biogás, glicerol.

\footnotetext{
${ }^{1}$ Mestre em Engenharia Agrícola, Programa de Pós Graduação em Engenharia Agrícola, Universidade Estadual do Oeste do Paraná (UNIOESTE), deia_larsen@hotmail.com.

${ }^{2}$ Prof. Associado, Centro de Ciências Exatas e Tecnológicas, Universidade Estadual do Oeste do Paraná (UNIOESTE), benedito.gomes@unioeste.br.

${ }^{3}$ Profa. Associada, Centro de Ciências Exatas e Tecnológicas, Universidade Estadual do Oeste do Paraná (UNIOESTE), simone.gomes@unioeste.br.

${ }^{4}$ Profa. Assistente, Curso Superior de Tecnologia em Biocombustíveis, Universidade Federal do Paraná (UFPR), dil.zenatti@ufpr.br.

${ }^{5}$ Doutorando em Engenharia Agrícola, Programa de Pós Graduação em Engenharia Agrícola, Universidade Estadual do Oeste do Paraná (UNIOESTE), douglasgbtorres@hotmail.com.
}

Recebido pelo Conselho Editorial em: 2-6-2010

Aprovado pelo Conselho Editorial em: 23-10-2012 


\section{INTRODUCTION}

All vegetable oils can be processed into biodiesel (SUAREZ et al., 2007). The main routes for obtaining biofuels from fats and oils are the transesterification, in which one triglyceride reacts with alcohol in the presence of catalysts and the cracking, which consists in breaking of molecules by high temperatures in the presence or absence of catalysts. The transesterification of vegetable oils consists in the reaction of triglycerides with a short-chain alcohol (ethanol or methanol) in the presence of an acid or basic catalyst, generating as products a mixture of alkyl esters (biodiesel), fatty acid and glycerin (FERRARI et al., 2005; ROBRA, 2006).

Glycerin is considered the main byproduct generated in the production of biodiesel, representing approximately $10 \%$ of the total volume of produced biodiesel (DASARI et al., 2005).

The glycerin obtained by the transesterification of vegetable oils (biodiesel production) has impurities such as water, alkali catalyst, unreacted alcohol and fatty acids, and other compounds. As the purification of glycerin is quite expensive, it is interesting to use the glycerin in processes that do not depend on high-purity level (MOTA \& PESTANA, 2011).

Launched on December $6^{\text {th }}, 2004$ by the Federal Government of Brazil, the Brazil's Biodiesel Production and Use Program relies on the growing demand for renewable fuels and Brazilian potential to attend a significant proportion of these needs.

In this context, alternatives to the use of crude glycerin, so this will not become an environmental and economic problem in the chain of production of biodiesel are being searched. The glycerin can be used in composting, in addition to other organic waste or generation of biogas by digestion of crude glycerine with other liquid or viscous waste, of easy microbial degradability (ROBRA, 2006).

The anaerobic co-digestion of organic waste can represent a large potential of contribution in renewable energy generation. The crude glycerin represents an excellent energy source for the microorganisms in anaerobic processes; however, by the absence of nitrogen and other nutrients in its composition, it can not be used as sole substrate, indicating their use in processes of codigestion. Some studies have evaluated the addition of glycerol in anaerobic reactors, treating different waste. AMON et al. (2006), HOLM-NIELSEN et al. (2008), CHEN et al. (2008) and WOHLGEMUT (2009) evaluated the addition of glycerin in animal waste. MA et al. (2008) evaluated the addition of wastewater in processing potatoes.

The residuary water of cassava starch industry (cassava wastewater), consisting of starch, sugars of easy degradation and nutrients (KUCZMAN et al., 2011; COLIN et al., 2007), can be considered as waste that can be co-digested with glycerin, for obtaining biogas. In the industry of cassava starch, the cassava wastewater is one of the most problematic waste, due to the high flow generation of the organic load (CAMPOS et al., 2006) and the presence of cyanogenic glycosides. Due to the glycerin presents high content of organic matter, readily degradable, the co-digestion must be constantly monitored in order to avoid compromising the stability and possible collapse of the reactor.

In this context, the aim of the study was to evaluate the process of anaerobic co-digestion of glycerin derived from biodiesel production with effluent from cassava starch industry in horizontal semi-continuous flow reactor of one phase, on a laboratory scale.

\section{MATERIAL AND METHODS}

The experiment was conducted in the Laboratory of Sanitation of the State University of West Paraná - (Universidade Estadual do Oeste do Paraná - UNIOESTE), Campus of Cascavel, located in Cascavel - State of Paraná (PR), Brazil. The cassava wastewater was collected at the entrance of the pond of sedimentation of the effluent treatment system of the cassava starch industry, located in the city of Toledo (PR), and transported to the Laboratory of Sanitation of UNIOESTE, Campus 
Cascavel, homogenized and preserved in freezer until its use. The crude glycerin derived from the methyl transesterification of soybean oil was collected in a biodiesel mill of a rural property located in the city of Toledo (PR).

The reactor used for anaerobic digestion was made with PVC pipe with a diameter of $200 \mathrm{~mm}$ and a length of $60 \mathrm{~cm}$, resulting in the total volume of the reactor of approximately $18.85 \mathrm{~L}$. Both extremities of the tube were sealed with PVC connections where PVC pipes of $20 \mathrm{~mm}$ were installed for input and output of effluent. The reactor was kept in a water bath at $26 \pm 1{ }^{\circ} \mathrm{C}$, submerged to the level of the substrate and operated in a horizontal position. As a support for the microorganisms, it was used rings of corrugated conduit of PVC with $20 \mathrm{~mm}$ of outer diameter, $2.3 \mathrm{~mm}$ of thick and $4 \mathrm{~cm}$ of length. The useful volume of the reactor was set at $8.77 \mathrm{~L}$, controlled by the height of the column of effluent in fermentation, daily verified.

The inoculation of the reactor was done with sludge of the anaerobic lagoon of the treatment system of the cassava starch industry, in proportion of $30 \%$ of inoculum, $10 \%$ of residuary water (cassava wastewater), and the remainder was completed with water. During the system startup, the reactor has received increasing organic loads of cassava wastewater until reach the load of $3.05 \mathrm{~g}$ COD L $\mathrm{L}^{-1} \mathrm{~d}^{-1}$, from which the addition of glycerin started. At the increase of the load it was verified the behavior of the reactor, by determination of $\mathrm{pH}$, volatile acidity (VA), total alkalinity (TA), $\mathrm{VA} / \mathrm{TA}$ ratio and biogas production, promoting increases when found the stabilization of the process.

In Figure 1 is shown the scheme of the treatment system adopted.

A peristaltic pump driven by timer distributed the feeding to the reactor over $24 \mathrm{~h}$ to simulate the continuous generation of industrial effluent. The withdrawal of the reactor effluent was performed in a daily basis, in an amount corresponding to the amount of substrate added, by suction through plastic hose.

The production of biogas was measured using a gasometer connected to the reactor by a PVC hose of $10 \mathrm{~mm}$. The gasometer was made with a PVC gallon of $20 \mathrm{~L}$, containing acidified saline solution of $25 \%$ of sodium chloride and $3 \%$ of sulfuric acid, which served as a water seal to prevent the output of biogas and to prevent the dissolution of the $\mathrm{CO}_{2}$ contained in the biogas.

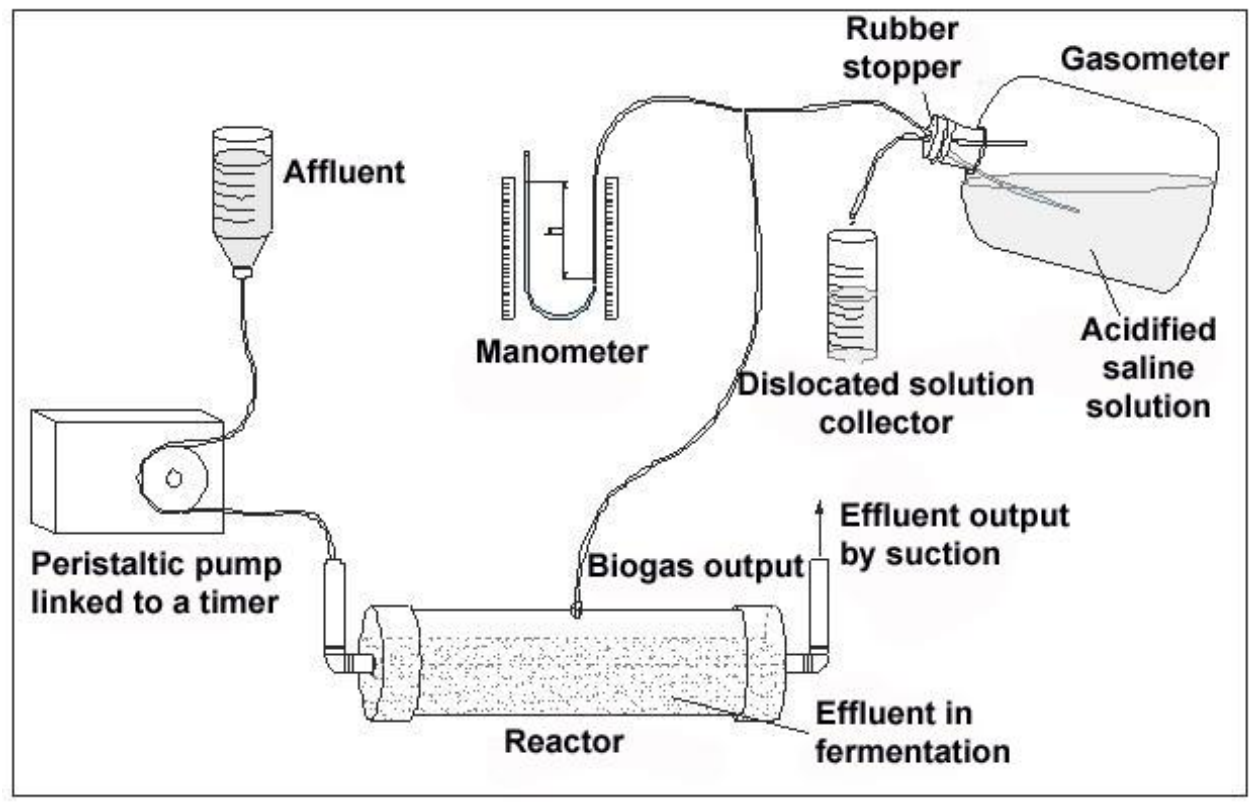

FIGURE 1. Scheme of the treatment system.

The determination of the volume of produced biogas was accomplished by measuring the fluid displaced from the gasometer. It was done the correction of this volume regarding humidity, related to a factor F, temperature and pressure, applying the eq.(1): 


$$
\frac{\mathrm{P}_{0} \mathrm{~V}_{0}}{\mathrm{~T}_{0}}=\frac{\mathrm{P}_{1} \mathrm{~V}_{1}}{\mathrm{~T}_{1}} \mathrm{~F}
$$

in which:

$\mathrm{P}_{0}$ - pressure on the CNTP, $\mathrm{mmHg}$;

$\mathrm{V}_{0}$ - volume in the CNTP, $\mathrm{L}$;

$\mathrm{T}_{0}$ - temperature in the CNTP, K;

$\mathrm{P}_{1}$ - local pressure of Cascavel - $\mathrm{PR}, \mathrm{mmHg}$;

$\mathrm{V}_{1}$ - measured volume, $\mathrm{L}$;

$\mathrm{T}_{1}$ - measured temperature, $\mathrm{K}$, and

$\mathrm{F}$ - correction factor of humidity.

The reactor was fed with cassava wastewater and glycerin, without correction of nutrients and $\mathrm{pH}$. Table 1 describes the volumetric organic load applied in the reactor during the experiment, the corresponding values of hydraulic retention time (HRT) and the levels of glycerin added to the cassava wastewater.

TABLE 1. Volumetric organic load used in the reactor during the experiment, HRT values and glycerin levels added to the cassava wastewater.

\begin{tabular}{cccc}
\hline $\begin{array}{c}\text { Volumetric Organic Load } \\
\left(\mathrm{g} \mathrm{COD} \mathrm{L}^{-1} \mathrm{~d}^{-1}\right)\end{array}$ & HRT $(\mathrm{d})$ & \% Cassava Wastewater & $\begin{array}{c}\text { Glycerin Levels } \\
(\%) \mathrm{v} / \mathrm{v})\end{array}$ \\
\hline 3.05 & 4 & 100 & 0 \\
9.32 & 5 & 98 & 2 \\
14.83 & 5 & 97 & 3 \\
13.59 & 4 & 98 & 2 \\
\hline
\end{tabular}

The sampling beginning of the reactor has occurred after a period equal to the HRT in study to eliminate the influence of earlier HRT. The samples were daily collected for 15 days for each treatment. The physico-chemical parameters determined on substrates, on the effluent and on the biogas were analyzed according to the methods indicated in Table 2.

The amount of methane contained in the biogas was measured by gas chromatography in the Laboratory of UNIOESTE, in the Cascavel Campus, with the GC-2010 Shimadzu chromatograph with Supel Q-PLOT column of $30 \mathrm{~m}$ x $0.53 \mathrm{~mm}$.

TABLE 2. Methods of analysis of the studied variables.

\begin{tabular}{ll}
\hline Parameter & Method \\
\hline $\mathrm{pH}$ & Potentiometric \\
Temperature & Direct - thermometer \\
Chemical oxygen demand (COD) & 5220D APHA (1999) - colorimetric \\
Volatile acidity (VA) & SILVA (1977) - volumetric \\
Total alkalinity (TA) & SILVA (1977) - volumetric \\
Total solids (TS) & 2540B APHA (1999) - gravimetric \\
Total fixed solids (TFS) & 2540B APHA (1999) - gravimetric \\
Total volatile solids (TVS) & 2540B APHA (1999) - gravimetric \\
Loss by dissection (humidity) & 012/IV - ADOLFO LUTZ INSTITUTE (1985) - \\
& gravimetric \\
Residue by incineration (ashes) & 018/IV - ADOLFO LUTZ INSTITUTE (1985) - \\
& gravimetric \\
\hline
\end{tabular}




\section{RESULTS AND DISCUSSION}

\section{Characterization of Substrates} Table 3.

The crude glycerin, as collected in the biodiesel mill, showed the characteristics described in

TABLE 3. Average composition of crude glycerin collected in the biodiesel industry in Toledo-PR.

\begin{tabular}{ll}
\hline Parameter & Value \\
\hline $\mathrm{pH}$ & 8.77 \\
Chemical oxygen demand (COD) & $1,900 \mathrm{~g} \mathrm{O}_{2} \mathrm{~L}^{-1}$ \\
Loss by dissection (humidity) & $79.96 \%(\mathrm{~m} / \mathrm{m})$ \\
Residue by incineration (ashes) & $4.35 \%(\mathrm{~m} / \mathrm{m})$ \\
\hline
\end{tabular}

The crude glycerin had alkaline $\mathrm{pH}$, which can be explained by the presence of residual $\mathrm{NaOH}$, used as catalyst in the production of biodiesel. It was also observed that the glycerin used showed great amounts of organic matter, 1,900 $\mathrm{g} \mathrm{O}^{2} \mathrm{~L}^{-1}$ of COD. MA et al. (2008) obtained a COD of $1,120 \mathrm{~g} \mathrm{O}^{2} \mathrm{~L}^{-1}$ for crude glycerine and $1,200 \mathrm{~g} \mathrm{O}^{2} \mathrm{~L}^{-1}$ for pure glycerol.

The addition of small amounts of glycerol to the effluent of the starch factory elevated the feeding volumetric organic load of the reactor. For its viscous characteristic, the addition of only $3 \%$ of glycerine $(\mathrm{m} / \mathrm{m})$ caused blockage of the reactor feed system, on a laboratory scale.

In the experiment it was also used three different lots of cassava wastewater, whose characteristics are presented in Table 4.

TABLE 4. Average composition of lots $01 ; 02$ and 03 of cassava wastewater collected on cassava starch industry in Toledo-PR.

\begin{tabular}{llll}
\hline Parameter & Lot 01 - 02/09 & Lot 02 - 03/09 & Lot 03 - 04/09 \\
\hline $\mathrm{pH}$ & - & 4.08 & 4.04 \\
Chemical oxygen demand (COD) & $12,194 \mathrm{mg} \mathrm{O}_{2} \mathrm{~L}^{-1}$ & $6,981 \mathrm{mg} \mathrm{O}_{2} \mathrm{~L}^{-1}$ & $14,937 \mathrm{mg} \mathrm{O}_{2} \mathrm{~L}^{-1}$ \\
Total solids (TS) & $9,670 \mathrm{mg} \mathrm{L}^{-1}$ & $6,480 \mathrm{mg} \mathrm{L}^{-1}$ & $7,560 \mathrm{mg} \mathrm{L}^{-1}$ \\
Total fixed solids (TFS) & $1,805 \mathrm{mg} \mathrm{L}^{-1}$ & $1,862 \mathrm{mg} \mathrm{L}^{-1}$ & $1,361 \mathrm{mg} \mathrm{L}^{-1}$ \\
Total volatile solids (TVS) & $7,865 \mathrm{mg} \mathrm{L}^{-1}$ & $5,119 \mathrm{mg} \mathrm{L}^{-1}$ & $6,199 \mathrm{mg} \mathrm{L}^{-1}$ \\
\hline
\end{tabular}

- Data not available

The cassava wastewater used in this study comes from different collections and different times of the year, approaching the reality of the company. This may explain the large variation of substrate composition between lots. The COD content varied between 6,981 and $14,937 \mathrm{mg} \mathrm{O}^{2} \mathrm{~L}^{-1}$. It was not possible to establish a correlation between the values of total solids, total volatile solids and COD. KUCZMAN (2007) used cassava wastewater from the same cassava starch of Toledo$\mathrm{PR}$, and obtained average concentration of COD in the order of 15,720 $\mathrm{mg} \mathrm{O}^{2} \mathrm{~L}^{-1}$.

The cassava wastewater used by CHAIPRASERT et al. (2003) also showed high concentrations of COD, ranging between 15,000 and 22,000 $\mathrm{mg} \mathrm{O}_{2} \mathrm{~L}^{-1}$. CAMPOS et al. (2006) had lower concentrations of COD in the cassava wastewater used, between 9,000 and $10,000 \mathrm{mg} \mathrm{O}^{2} \mathrm{~L}^{-1}$. The technology used in the manufacturing process can affect the composition of cassava wastewater, as can be seen in Table 4.

\section{Removal of COD and solids}

The feeding organic load of the reactor was used in the following order: 3.05, 9.32, 14.83 and $13.59 \mathrm{~g} \mathrm{COD} \mathrm{L}^{-1} \mathrm{~d}^{-1}$. In the fourth experimental treatment, the reactor showed signs of overload at 
the end of the period of data collection, checked with the increase of the VA/TA and decreased production of biogas.

Nevertheless, in the four treatments, the reactor showed good COD removal, which ranged between 91.54 and $98.69 \%$. Table 5 shows the average values of COD removal, for each load evaluated. In Figure 2 it can be seen the behavior of the COD concentration of the effluent and removal during maintenance of the respective loads.

TABLE 5. Comparison of average reduction of COD for organic load tested.

\begin{tabular}{ccccc}
\hline Load & Concentration of Glycerin $(\%)$ & \multicolumn{2}{c}{ Average COD $\left(\mathrm{mg} \mathrm{L}^{-1}\right)$} & \multirow{2}{*}{ Removal $(\%)$} \\
\cline { 1 - 4 }$\left(\mathrm{g} \mathrm{COD} \mathrm{L}^{-1} \mathrm{~d}^{-1}\right)$ & $(\mathrm{v} / \mathrm{v})$ & Affluent & Effluent & \\
\hline 3.05 & 0 & 12,195 & 437.6 & $96.41 \pm 0.42$ \\
9.32 & 2 & 46,609 & 610 & $98.69 \pm 0.69$ \\
14.83 & 3 & 74,141 & 1,044 & $98.59 \pm 0.12$ \\
13.59 & 2 & 54,406 & $4,600.1$ & $91.54 \pm 23.88$ \\
\hline
\end{tabular}

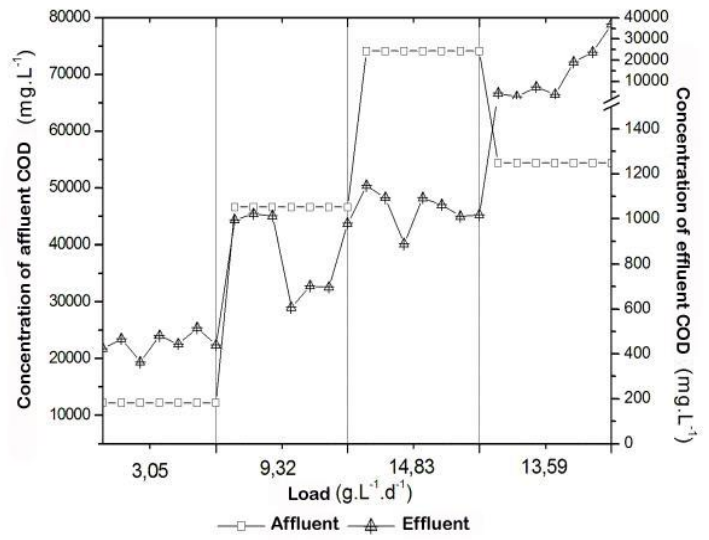

(a)

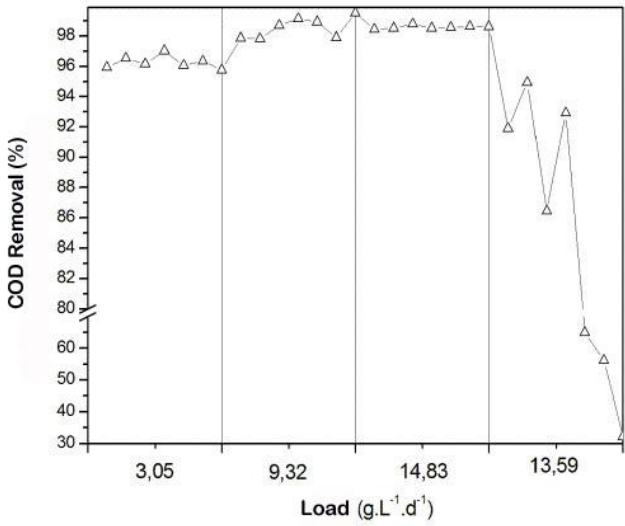

(b)

FIGURE 2. COD concentration in affluent and effluent (a) and COD removal (b), for each applied volumetric organic load.

For the treatments with organic load input of 9.32 and $14.83 \mathrm{~g} \mathrm{COD} \mathrm{L}^{-1} \mathrm{~d}^{-1}$, the average of COD removal showed similar values, and these removals were greater than the COD removal of the control treatment without addition of glycerin. The lowest average of removal, $91.54 \%$, happened to the organic load of $13.59 \mathrm{~g} \mathrm{COD} \mathrm{L}^{-1} \mathrm{~d}^{-1}$ and HRT of $4 \mathrm{~d}$, explained by the increase of the VA/TA in the reactor.

MA et al. (2008) obtained a COD reduction of around $85 \%$ in the UASB reactor in the treatment of residual water of processing potatoes with the addition of glycerol at a rate of $2 \mathrm{~mL}$ of glycerol per liter of residual water. WOHLGEMUT (2009) performed batch tests to evaluate the addition of crude glycerol and pure glycerol in anaerobic digestion of swine manure, obtaining the greatest reduction of COD $(57 \%)$ for the addition of $1 \%(\mathrm{~m} / \mathrm{m})$ of pure glycerol in the reactor. In the anaerobic reactor of semi-continuous flow obtained a greater reduction of COD, of $74 \%$, also for the addition of $1 \%(\mathrm{~m} / \mathrm{m})$ of pure glycerol.

Table 6 presents the average of reduction of total solids and total volatile solids to the evaluated organic load and Figure 3 shows the values of removal during maintenance of the individual loads. 
TABLE 6. Comparison of averages of reduction of TS and TVS for the tested organic load.

\begin{tabular}{cccc}
\hline $\begin{array}{c}\text { Volumetric organic } \\
\text { load }\end{array}$ & $\begin{array}{c}\text { Concentration of Glycerin } \\
\left(\mathrm{g} \mathrm{COD} \mathrm{L}^{-1} \mathrm{~d}^{-1}\right)\end{array}$ & Removal TS (\%) & Removal TVS (\%) \\
\hline 3.05 & 0 & $81.19 \pm 2.96$ & $90.21 \pm 2.30$ \\
9.32 & 2 & $75.47 \pm 6.43$ & $81.18 \pm 9.50$ \\
14.83 & 3 & $68.79 \pm 9.79$ & $72.24 \pm 10.06$ \\
13.59 & 2 & $55.58 \pm 12.96$ & $61.45 \pm 13.27$ \\
\hline
\end{tabular}

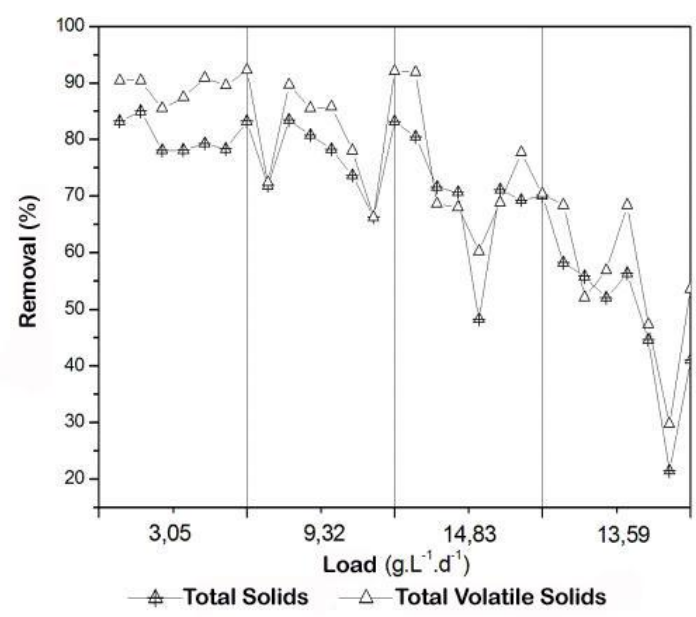

FIGURE 3. Values of efficiency of total solids and total volatile solids, for each applied volumetric organic load.

It can be observed that the removal rate of TS declined over the treatments, reaching $55.58 \%$ to the organic load of $13.59 \mathrm{~g} \mathrm{COD} \mathrm{L}^{-1} \mathrm{~d}^{-1}$. The highest removal, $81.19 \%$ occurred for the organic load rate of $3.05 \mathrm{~g} \mathrm{COD} \mathrm{L}^{-1} \mathrm{~d}^{-1}$ without the addition of glycerin to the substrate to be digested. This value is smaller than that obtained by KUCZMAN (2007), of 98.11\%, which utilized plug-flow reactor, without filling, in the treatment of cassava wastewater of the same starch industry, with organic load input of $1.57 \mathrm{~g} \mathrm{COD} \mathrm{L}^{-1} \mathrm{~d}^{-1}$. Similar to the reduction of total solids, the removal of total volatile solids declined over the treatments. Again, the greater removal occurred to the organic load of $3.05 \mathrm{~g} \mathrm{COD} \mathrm{L}^{-1} \mathrm{~d}^{-1}$ without the addition of glycerin to the substrate to be digested. KUCZMAN (2007) achieved the highest reduction of TVS, 99\%, with HRT of 8.27 days for loading $1.57 \mathrm{~g} \mathrm{COD} \mathrm{L}^{-1} \mathrm{~d}^{-1}$.

RIBAS \& BARANA (2003), evaluating a plug-flow reactor of one phase in the treatment of cassava wastewater, had the greatest reductions in TS and TVS, 58\% and 79\%, respectively, using the organic load rate of $0.86 \mathrm{~g} \mathrm{COD} \mathrm{L}^{-1} \mathrm{~d}^{-1}$ for the HRT of 4 days. I.e., the removals were lower than those of the present study regarding the treatment that was used only the cassava wastewater as affluent with volumetric organic load rate of $3.05 \mathrm{~g} \mathrm{COD} \mathrm{L}^{-1} \mathrm{~d}^{-1}$.

BANU et al. (2006) studied the anaerobic treatment of effluent from 'sagu' processing industry in an upflow anaerobic sludge blanket (UASB) with organic load ranging from 10.7 to $24.7 \mathrm{~g} \mathrm{COD} \mathrm{L}^{-1} \mathrm{~d}^{-1}$ and observed that the removal of total solids was between 57 and $61 \%$ and of total volatile solids between 67 and $70 \%$. These results are similar to the values of removal obtained in this study for treatments with volumetric organic load of $14.83 \mathrm{~g} \mathrm{COD} \mathrm{L}^{-1} \mathrm{~d}^{-1}$ and $13.59 \mathrm{~g} \mathrm{COD} \mathrm{L}^{-1} \mathrm{~d}^{-1}$.

COLIN et al. (2007) evaluated the effect of bamboo as support for microorganisms, in horizontal flow filter in cassava wastewater fermentation from the industry of sour starch and had a $67 \%$ reduction of total suspended solids to the organic load of $5.3 \mathrm{~g} \mathrm{COD} \mathrm{L}^{-1} \mathrm{~d}^{-1}$, with HRT of 
$9.2 \mathrm{~h}$, lower than the removal obtained in this study for treatment without addition of glycerin, with volumetric organic load of $3.05 \mathrm{~g} \mathrm{COD} \mathrm{L}^{-1} \mathrm{~d}^{-1}$, but with HRT of 4 days.

CHEN et al. (2008) investigated the co-digestion of manure and glycerine in continuous anaerobic reactor of complete mixture. For the treatment with $45 \%$ of glycerin and $55 \%$ of manure, with HRT of 20 days, they obtained a reduction of TVS between 58 and $67 \%$ higher than the values obtained from this study for treatment with $2 \%$ glycerol and organic load rate of $13.59 \mathrm{~g} \mathrm{COD} \mathrm{L}^{-1} \mathrm{~d}^{-1}$.

\section{Biogas production}

Table 7 shows the average results of specific production of biogas as a function of the reactor volume, the consumption of COD and TVS for the volumetric organic load applied. In Figure 4 it is possible to see the behavior of these results, during reactor operation, under each of the volumetric organic load applied.

TABLE 7. Average values of biogas production per volume of reactor, per $g$ of COD consumed and $\mathrm{g}$ of TVS consumed for the organic load tested.

\begin{tabular}{ccclc}
\hline $\begin{array}{c}\text { Organic load } \\
\left(\mathrm{g} \mathrm{COD} \mathrm{L}^{-1} \mathrm{~d}^{-1}\right)\end{array}$ & $\begin{array}{c}\text { Concentration of } \\
\text { glycerin }(\%)(\mathrm{v} / \mathrm{v})\end{array}$ & $\mathrm{L} \mathrm{L}^{-1} \mathrm{~d}^{-1}$ & $\begin{array}{c}\mathrm{L} \mathrm{g}^{-1} \mathrm{COD} \\
\text { consumed }\end{array}$ & $\begin{array}{c}\mathrm{L} \mathrm{g} \mathrm{g}^{-1} \mathrm{TVS} \\
\text { consumed }\end{array}$ \\
\hline 3.05 & 0 & $1.168 \pm 0.17$ & $0.397 \pm 0.06$ & $0.661 \pm 0.10$ \\
9.32 & 2 & $1.979 \pm 0.42$ & $0.025 \pm 0.005$ & $0.189 \pm 0.05$ \\
14.83 & 3 & $1.305 \pm 0.24$ & $0.089 \pm 0.02$ & $0.097 \pm 0.02$ \\
13.59 & 2 & $0.861 \pm 0.37$ & $0.069 \pm 0.03$ & $0.089 \pm 0.03$ \\
\hline
\end{tabular}

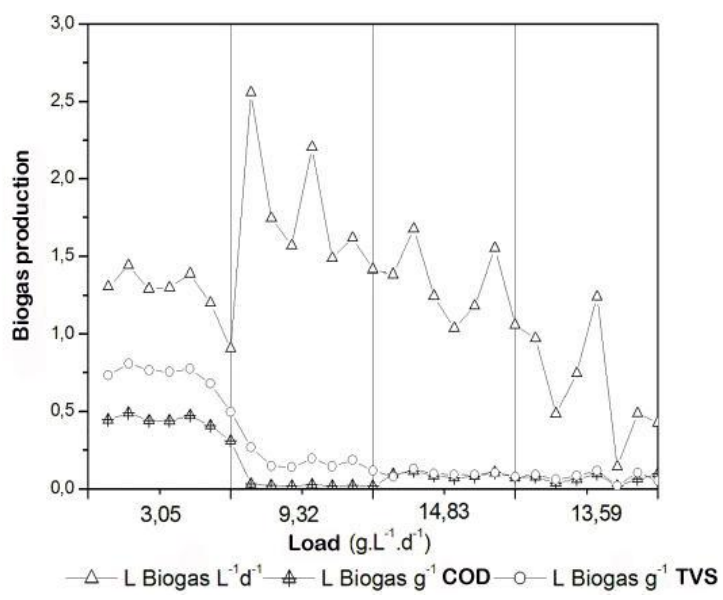

FIGURE 4. Biogas production during the reactor operation, for each applied volumetric organic load.

With the addition of $2 \%$ of glycerin in the reactor, with charge of $9.32 \mathrm{~g} \mathrm{~L}^{-1} \mathrm{~d}^{-1}$, the average biogas production increased from 1.168 to $1.979 \mathrm{~L}^{-1} \mathrm{~d}^{-1}$, which corresponded to a higher average production of biogas, among the applied treatments. The analysis of biogas at the end of this treatment indicates the presence of $48.31 \%$ of methane. By adding 3\% of glycerin, the average biogas decreased to $1.305 \mathrm{~L}^{-1} \mathrm{~d}^{-1}$, which may be due to the accumulation of volatile fatty acids and glycerol in the reactor, with consequent inhibition of the methanogenic archaea. The biogas showed $29.21 \%$ of methane at the end of this treatment. For the last treatment tested, the average biogas was reduced to $0.861 \mathrm{~L}^{-1} \mathrm{~d}^{-1}$, when it was observed the increase of the VA/TA in the reactor.

The highest specific production of biogas in function of the consumption of COD was 0.397 , observed in the treatment with the organic load applied in $3.05 \mathrm{~g} \mathrm{COD} \mathrm{L}^{-1} \mathrm{~d}^{-1}$. In other treatments, where glycerin was added to the substrate, the rate of conversion of organic matter into biogas was lower. 
KUCZMAN (2007) studied the treatment of effluent of starch industry in a horizontal reactor of one phase and achieved the best average of biogas production, 0.654 and $0.627 \mathrm{~L}^{-1} \mathrm{~d}^{-1}$, in the hydraulic retention times of 8.27 and 6.59 days, which corresponded to the volumetric organic load applied in 1.57 and $2.68 \mathrm{~g} \mathrm{COD} \mathrm{L}^{-1} \mathrm{~d}^{-1}$, respectively. The author had the highest specific production average of biogas as a function of the consumed COD $\left(0.817 \mathrm{~L} \mathrm{~g}^{-1}\right)$ for the HRT of organic load rate of 8.27 to $1.57 \mathrm{~g} \mathrm{COD} \mathrm{L}^{-1} \mathrm{~d}^{-1}$, higher than the obtained in this study, $0.397 \mathrm{~g} \mathrm{~L}^{-1} \mathrm{~d}^{-1}$ for the treatment without adding glycerin and volumetric organic load of $3.05 \mathrm{~g} \mathrm{COD} \mathrm{L}^{-1} \mathrm{~d}^{-1}$.

WOHLGEMUT (2009) achieved the highest production of methane, 0,41 m $\mathrm{CH}^{4} \mathrm{~kg}^{-1} \mathrm{COD}$ consumed, for the addition of $2 \%(\mathrm{~g} / \mathrm{g})$ of glycerol in pure anaerobic digestion of swine manure, in semi-continuous reactor. For the batch testing, the author had the highest biogas production for the addition of $0.5 \%(\mathrm{~g} / \mathrm{g})$ of pure glycerol $\left(0.61 \mathrm{~m}^{3}\right.$ biogas kg${ }^{-1}$ COD consumed). For the addition of $2 \%(\mathrm{~g} / \mathrm{g})$ of crude glycerine obtained $0.91 \mathrm{~m}^{3}$ biogas $\mathrm{kg}^{-1}$ COD consumed, with their respective productions of methane of 0.11 and $0.29 \mathrm{~m}^{3} \mathrm{CH} 4 \mathrm{~kg}^{-1} \mathrm{CODc}$, volumes higher than those obtained in this study for treatments with addition of $2 \%$ and $3 \%$ of glycerol and volumetric organic load of $9.32 \mathrm{~g}$ and $14.83 \mathrm{~g} \mathrm{COD} \mathrm{L}^{1} \mathrm{~d}^{-1}$, respectively.

CHAIPRASERT et al. (2003) studied cassava wastewater of starch industry by treatment with mineral supplement in hybrid upflow reactors with support for nylon fibers. They obtained biogas production of $0.27 \mathrm{~L} \mathrm{gas} \mathrm{g}^{-1}$ of COD consumed with organic load of $4 \mathrm{~g} \mathrm{COD} \mathrm{L}^{-1} \mathrm{~d}^{-1}$ and HRT of $5.4 \mathrm{~d}$. COLIN et al. (2007) obtained an average biogas production of $0.36 \mathrm{~L} \mathrm{~g}^{-1}$ of COD consumed, evaluating a horizontal flow filter with bamboo support through the fermentation of cassava wastewater from sour starch industry. The result was close to that obtained in the present study, of $0.397 \mathrm{~L} \mathrm{gas} \mathrm{g}^{-1}$ of COD consumed for treatment without addition of glycerin with volumetric organic load of $3.05 \mathrm{~g} \mathrm{COD} \mathrm{L}^{-1} \mathrm{~d}^{-1}$.

ROBRA (2006) studied the treatment of cattle manure and glycerin in UASB reactor. For 0\%

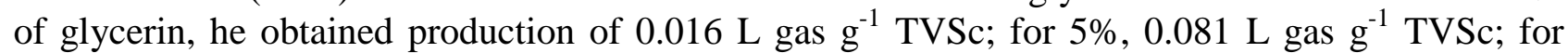
$10 \%, 0.110 \mathrm{~L}$ gas $\mathrm{g}^{-1}$ TVSc; for $15 \%, 0.062 \mathrm{~L}_{\text {gas }} \mathrm{g}^{-1}$ TVSc. That is, the biogas production increased with the addition of glycerol in the reactor, until the limit of addition of $10 \%$. In the present study, the specific production by TVS consumed decreased from the addition of glycerol to the cassava wastewater.

AMON et al. (2006) studied the anaerobic digestion of a mixture of $31 \%$ corn silage, $15 \%$ corn grains and $54 \%$ swine manure with addition of different percentages of glycerin $(3 \%, 6 \%, 8 \%$ and $15 \%$ ). The supplementation with $6 \%$ of glycerin resulted in an increased methane production of about $19 \%$.

CHEN et al. (2008), obtained, after 14 days of digestion in batch reactor, biogas production of $0.67,0.19,0.51$ and $0.37 \mathrm{~L} \mathrm{~g}^{-1}$ TVS for glycerin, cattle manure and Mixture 1 (60\% of glycerine and $40 \%$ of cattle manure) and Mixture 2 (45\% of glycerin and 55\% of cattle manure) respectively, and corresponding production of methane of $0.35,0.14,0.31$ and $0.22 \mathrm{~L} \mathrm{~g}^{-1}$ TVS 1 . The digestion in continuous reactor of complete mixture type, with HRT of $20 \mathrm{~d}$, resulted in average biogas production of $0.43 \mathrm{~L} \mathrm{~g}^{-1}$ TVS to the organic load of $0.5 \mathrm{~g} \mathrm{TVS} \mathrm{d}^{-1}$. However, to the organic load of $1.0 \mathrm{~g} \mathrm{TVS} \mathrm{d}^{-1}$, the reactor $\mathrm{pH}$ declined to 6.32 and the biogas production decreased to $0.37 \mathrm{~L} \mathrm{~g}^{-1}$ TVS. Decreasing the volume of glycerol to $45 \%$ (Mixture 2) the $\mathrm{pH}$ of the reactor was increased to 6.84 and the production of biogas to $0.47 \mathrm{~L} \mathrm{~g}^{-1} \mathrm{TVS}$, production higher than the obtained in the present study for the treatments with addition of glycerin, with a maximum production of $0.189 \mathrm{~L} \mathrm{~g}^{-1}$ TVS, for the addition of $2 \%$ of glycerol and volumetric organic load of $9.92 \mathrm{~g} \mathrm{COD} \mathrm{L}^{-1} \mathrm{~d}^{-1}$.

\section{Volatile acidity and total alkalinity}

Table 8 presents the averages of total alkalinity, volatile acidity and $\mathrm{pH}$ for the volumetric organic load tested. 
TABLE 8. Average of total alkalinity, volatile acidity and $\mathrm{pH}$ for the volumetric organic load tested.

\begin{tabular}{lccccc}
\hline Load & $\begin{array}{c}\text { Concentration of } \\
\text { glycerin }(\% \mathrm{v} / \mathrm{v})\end{array}$ & $\begin{array}{c}\text { Total Alkalinity } \\
\left(\mathrm{mg} \mathrm{CaCO}_{3} \mathrm{~L}^{-1}\right)\end{array}$ & $\begin{array}{c}\text { Volatile Acidity }(\mathrm{mg} \\
\left.\left(\mathrm{CH}_{3} \mathrm{COOH}\right) \mathrm{L}^{-1}\right)\end{array}$ & $\mathrm{VA} / \mathrm{TA}$ & $\mathrm{pH}$ \\
\hline 3.05 & 0 & 953.53 & 100.93 & $0.11 \pm 0.05$ & $7.71 \pm 0.25$ \\
9.32 & 2 & 673.00 & 281.70 & $0.43 \pm 0.14$ & $7.48 \pm 0.67$ \\
14.83 & 3 & 786.46 & 307.17 & $0.43 \pm 0.20$ & $7.82 \pm 0.30$ \\
13.59 & 2 & 993.43 & 4719.91 & $4.75 \pm 0.01$ & $4.85 \pm 0.10$ \\
\hline
\end{tabular}

Figure 5 shows the results of volatile acidity/total alkalinity (VA/TA) and reduction of COD relation and VA/TA and $\mathrm{pH}$ relation in the reactor, as a function of volumetric organic load applied.

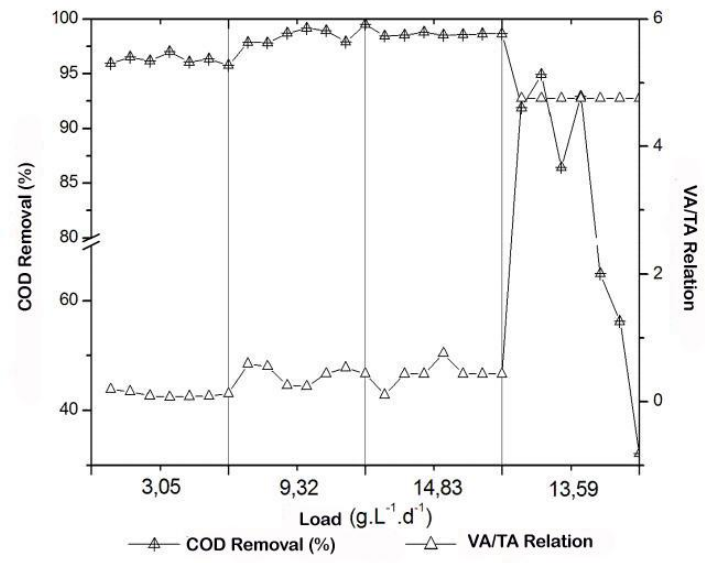

(a)

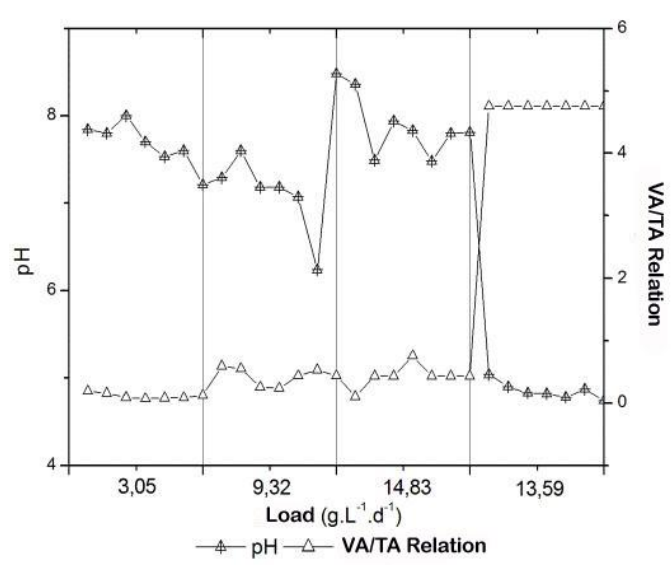

(b)

FIGURE 5. VA/TA Relation and COD Reduction (a) and VA/TA and $\mathrm{pH}$ Relation (b) for the volumetric organic load applied.

It is possible to verify that the largest reductions of COD occurred with values of VA/TA relation below 1 . When the VA/TA relation increased to values near 5, the removal of COD declined, indicating that the methanogenic microorganisms begin to be inhibited.

HOLM-NIELSEN et al. (2008) studied the anaerobic digestion of a mixture of manure, waste from food industries and glycerol added to the reactor gradually. The authors observed the accumulation of volatile fatty acids and glycerol in the reactor with the addition of 3.5 to $6.5 \%$ of glycerol (v/v), from the 16th to the 19th day of the experiment, which caused the inhibition of the methanogenic phase. According to SILVA (1977), the accumulation of volatile organic acids indicates the imbalance between velocities of organic matter consume of different types of bacteria, responsible for the proper performance of the anaerobic treatment system. When the concentration of volatile acids exceeds about $500 \mathrm{mg} \mathrm{L}^{-1}$, or better, when there is no buffer effect due to the absence of alkalinity to bicarbonate, there is a probability to occur serious problems with the treatment system due to the $\mathrm{pH}$ decrease. This was observed in the present study, in which the concentration of volatile acids exceeded $500 \mathrm{mg} \mathrm{L}^{-1}$ for the treatment with volumetric organic load of $13.59 \mathrm{~g} \mathrm{COD} \mathrm{L}^{-1} \mathrm{~d}^{-1}$, leading to decreased production of biogas.

\section{CONCLUSIONS}

The process of anaerobic co-digestion of cassava wastewater with addition of glycerin showed high COD removal, the range is from 91.54 to $98.69 \%$ for loads of 3.05 ; 9.32 and $14.83 \mathrm{~g} \mathrm{~L}^{-1} \mathrm{~d}^{-1}$. In the last organic load applied, of $13.59 \mathrm{~g} \mathrm{~L}^{-1} \mathrm{~d}^{-1}$, there was increased volatile acidity, with consequent increase of the VA/TA and reduction of organic matter removal.

The average removal efficiencies of TS and TVS were decreasing from the addition of glycerin to cassava wastewater, averaging 81.19 to $55.58 \%$ for TS and 90.21 to $61.45 \%$ for TVS. 
The addition of glycerin at $2 \%$ increased biogas production compared to the control treatment, reaching $1.979 \mathrm{~L} \mathrm{~L}^{-1} \mathrm{~d}^{-1}$ and methane content of $48.31 \%$. However, the biogas production decreased for adding $3 \%$ of glycerin and at this ratio caused clogging in the feeding system of the reactor on a laboratory scale. The production of biogas as a function of the COD consumed was higher for the control treatment than for the treatment with addition of glycerin, which indicates lower conversion of organic matter into biogas.

\section{ACKNOWLEDGEMENTS}

To the National Counsel of Technological and Scientific Development (Conselho Nacional de Desenvolvimento Científico e Tecnológico - CNPq) for the financial support.

\section{REFERENCES}

AMON, T.; AMON, B.; KRYVORUCHKO, V.; BODIROZA, V.; PÖTSCH, E.; ZOLIITSCH, W. Optimising methane yield from anaerobic digestion of manure: effect of dairy systems and of glycerine supplementation. International Congress Series, Amsterdam, v.1293, p.217-220, 2006.

APHA - AMERICAN PUBLIC HEALTH ASSOCIATION. Standard methods for the examination of water and wastewater. 20th ed. Washington, 1999.

BANU, J. R.; KALLIAPAN, S.; BECK, D. High rate anaerobic treatment of Sago wastewater using HUASB with PUF as carrier. International Journal of Environmental Science and Technology, Chennai, v.3, n.1, p.69-77, 2006.

CAMPOS, A. T.; DAGA, J.; RODRIGUES, E. E.; FRANZENER, G.; SUGUIY, M. M.; SYPERREC, V. L. G. Tratamento de águas residuárias de fecularia por meio de lagoas de estabilização. Engenharia Agrícola, Jaboticabal, v.26, n.1, p.235-242, jan./abr.2006.

CHAIPRASERT, P.; SUVAJITTANONT, W.;SURARAKSA, B.; TANTICHAROEN, M. ; BHUMIRATANA, S. Nylon fibers as supporting media in anaerobic hybrid reactors: it's effects on system's performance and microbial distribution. Water Research, New York, v.37, p.4605-4612, 2003.

CHEN, X.; ROMANO, R. T.; ZHANG, R.; KIM, H. Anaerobic co-digestion of dairy manure and glycerin. In: 2008 ASABE ANNUAL MEETING, 2008, Providence, Rhode Island.

COLIN, X.; FARINET, J.-L.; ROJAS, O.; ALAZARD, D. Anaerobic treatment of cassava starch extraction wastewater using a horizontal flow filter with bamboo as support. Bioresource Technology, Essex, v.98, p.1602-1607, may 2007.

DASARI, M.A.; KIATSIMKUL, P.; SUTTERLIN, W.R.; SUPPES, G.J. Low-pressure hydrogenolusis of glycerol to propylene glycol. Applied Catalysis, Amsterdam, n.281, p.225-231, 2005.

FERRARI, R.A.; OLIVEIRA, V.S.; SCABIO, A. Biodiesel de soja - Taxa de conversão de ésteres etílicos, caracterização físico-química e consumo gerado de energia. Química Nova, São Paulo, v.28, n.1, p.19-23, 2005.

HOLM-NIELSEN, J. B.; LOMBORG, C. J.; OLESKOWICZ-POPIEL, P.; ESBENSEN, K. H. Online near infrared monitoring of glycerol-boosted anaerobic digestion processes: evaluation of process analytical technologies. Biotechnology \& Bioengineering, v.99, n.2, p.302-313, fev. 2008.

INSTITUTO ADOLFO LUTZ. Métodos físico-químicos para análise de alimentos. 4.ed. digital. São Paulo, 2008.

KUCZMAN, O. Tratamento anaeróbio de efluente de fecularia em reator horizontal de uma fase. 2007. 70 f. Dissertação (Mestrado em Engenharia Agrícola) - Centro de Ciências Exatas e Tecnológicas, Universidade Estadual do Oeste do Paraná, Cascavel. 
KUCZMAN, O.; GOMES, S. D.; TAVARES, M. H. F.; DOUGLAS, G. B.; TORRES, D. G. B.; ALCÂNTARA, M. S. Produção específica de biogás a partir de manipueira em reator de fase única. Engenharia Agrícola, Jaboticabal, v.31 n.1, p.143-149, jan./fev. 2011.

MA, J.; WAMBEKE, M. V.; CARBALLA, M.; VERSTRAETE, W. Improvemente of potato processing wastewater in a UASB reactor by co-digestion with glicerol. Biotechnology Letters, Dordrecht, v.30, p.861-867, 2008.

MOTA, C. J. A.; PESTANA, C. F. M. Co-produtos da produção de biodiesel. Revista Virtual Química, Niterói, v.3, n.5, p.416-425, out. 2011

RIBAS, M. M. F.; BARANA. A. C. Start-up adjustment of a plug-flow digester for cassava wastewater (manipueira) treatment. Scientia Agrícola, Piracicaba, v.60, n.2, p.223-229, abr./jun. 2003.

ROBRA, S. Uso da glicerina bruta em biodigestão anaeróbica: aspectos tecnológicos, ambientais e ecológicos. 2006. 120 f. Dissertação (Mestrado em Desenvolvimento Regional e Meio Ambiente) Universidade Estadual de Santa Cruz, Ilhéus, 2006.

SILVA, M. O. S. A. Análises físico-químicas para controle de estações de tratamento de esgotos. São Paulo: CETESB, 1977. 226 p.

SUAREZ, P. A. Z.; SIMONI M.; PLENTZ MENEGHETTI, S. M. P.; MENEGHETTI, M. R.; WOLF, C. R. Transformação de triglicerídeos em combustíveis, materiais poliméricos e insumos químicos: algumas aplicações da catálise na oleoquímica. Química Nova, São Paulo, v.30, n.3, p.667-676, 2007.

WOHLGEMUT, O. Co-digestion of hog manure with glicerol to boost biogás and methane production. 2009. 90 f. Dissertação (Mestrado) - Faculty of Graduate Studies, University of Manitoba, Winnipeg, 2009. 